\title{
Knowledge, attitude, and utilization of HIV counseling and testing by female sex workers in Lagos State, Nigeria
}

\author{
Ogunyemi $\mathrm{AO}^{1}$, Ogunmefun $\mathrm{OT}^{1}$, Oluwole $\mathrm{EO}^{1}$, Ekundayo $\mathrm{AA}^{2}$ \\ ${ }^{1}$ Department of Community Health and Primary Care, College of Medicine, University of Lagos, Nigeria \\ ${ }^{2}$ Department of Community Medicine and Primary Care, Olabisi Onabanjo University, Ago-Iwoye, \\ Nigeria
}

Submitted: $6^{\text {th }}$ June 2020

Accepted: $18^{\text {th }}$ July 2020

Published: 30 $30^{\text {th }}$ December 2020

\begin{abstract}
Objectives: The Human Immunodeficiency Virus (HIV) epidemic continues to expand among female sex workers (FSWs) who have limited access to and utilization of HIV counseling and testing services (HCT). HCT plays a pivotal role in increasing knowledge and awareness to prevent, treat, and control HIVIAIDS. The study objective was to determine the knowledge, attitude, utilization of HCT among brothel-based FSWs (BBFSWs). Method: This was a descriptive cross-sectional study among 300 BBFSWs in Lagos State. The respondents were recruited by snowballing after a multistage sampling method was used in the selection of the brothels. The data was collected using an adapted interviewer-administered questionnaire and analyzed using IBM SPSS Statistics version 23. The level of statistical significance was set at $p<0.05$.

Results: Majority $(63.0 \%)$ of the respondents were between the ages of $21-30$ years and $67.4 \%$ had good knowledge of HIV and HCT. About $75.0 \%$ had a positive attitude towards HCT and $55.6 \%$ of FSWs in this study had utilized an HCT center in the past. The main reason for not taking HIV test was the fear of a positive result $(90.6 \%)$ while the main reasons given for not visiting any HCT center were lack of confidentiality $(13.3 \%)$, stigmatization $(14.8 \%)$, and distance to the HCT center $(67.2 \%)$.

Conclusion: There was a good knowledge of HCT and a positive attitude towards HCT services by the respondents. The main reasons for not taking the HIV test as indicated by respondents were fear of a positive result. HIV-stigma related issues should be adequately addressed.
\end{abstract}

Keywords: Attitude, BBFSWs, HCT, Knowledge, Utilization

\section{Plain English Summary}

The HIVIAIDS epidemic continues to expand among female sex workers (FSWs) who have limited access and utilization of HIV counseling and testing services (HCT). HCT plays a pivotal role in increasing knowledge and awareness to prevent, treat, and control HIVIAIDS. This study aimed to determine the knowledge, attitude, and utilization of HCT centers among brothel-based FSWs (BBFSWs). This was a descriptive cross-sectional study among 300 BBFSWs brothel-based FSWs in Lagos State. The respondents were recruited by firstly identifying a few female sex workers who then invited their co-workers to participate in the study. The data was collected by trained interviewers with an adapted questionnaire. The data were analyzed using the Statistical Package for Social Sciences. The majority of the respondents were between the ages of $21-30$ years and $67.4 \%$ had good knowledge of HIV and HCT. About $75.0 \%$ had a positive attitude towards HCT and $55.6 \%$ of FSWs in this study had utilized an HCT center in the past. The main reason for not taking the HIV test was fear of a positive result $(90.6 \%)$ while the main reason given for not visiting any HCT center was the distance to the HCT center $(67.2 \%)$. More HCT centers should be made available for use. 


\section{Background}

The access point to prevention, treatment, and control of human immunodeficiency virus (HIV) infection is HIV Counselling and Testing (HCT) (1). HCT is the process whereby an individual or a couple undergoes counseling to enable them to make informed choices about being tested for HIV. HIV infection among female sex workers (FSWs) plays an important role in the development of HIV epidemics in many regions of the world and has a significant potential to cause HIV transmission to the general population, with male clients serving as the bridging population $(2,3)$. HIVIAIDS has currently neither a cure nor a reliable vaccine (4). The control remains entirely on either preventing the infection of healthy people from acquiring the infection or containing the problem size to the minimum that would enable those already infected persons to live longer, healthy and remain non-infective to others (5). HCT centers offer reliable HIVIAIDS information and serve as a continuum for HIV prevention, care, treatment, and support services (1).

Lack of information and access to services by FSWs, as well as the distance to HCT facilities, is expected to fuel the HIVIAIDS epidemic (6, 7). Lack of knowledge regarding the importance of HCT and stigmatization has been identified as major factors affecting the uptake of HCT. Given the public health importance of HIVIAIDS, the utilization of HCT service in Nigeria is low; only $26.3 \%$ of Nigerians have ever tested for HIV (8).

Fulfilling the Joint United Nations Programme on HIV and AIDS (UNAIDS) 2010 vision of zero new infections will require careful consideration of the societal structures, beliefs, and value systems that present obstacles to effective HIV prevention efforts (9). Despite the significance of HCT in HIV control, access to HCT services by high-risk groups like FSWs in sub-Saharan Africa remains at a suboptimal level $(10,11)$. Due to the paucity of data especially among BBFSWs in the commercial nerve center of Nigeria, Lagos State, this study aimed to fill the knowledge gap and guide HIV programmers to address challenges in HTC service delivery.

\section{Methods}

This was a descriptive cross-sectional study among brothel-based FSWs. The inclusion criteria were female sex workers aged 18 years and above who were living in brothels and were involved in sex work. A sample size of 300 was calculated using the Cochrane's formula (12) based on the prevalence of $26.0 \%$ in a previous study (13) of sex workers' knowledge on HCT to give a $95 \%$ confidence interval and margin of error of $\pm 5 \%$.

A multistage sampling method was employed in the selection of a representative sample from the source population. Stage 1 involved the selection of three of the 5 administrative divisions in Lagos State using simple random sampling (by balloting) and they were Ikeja, Badagry, and Lagos divisions. In stage 2, one Local Government Area (LGA) was selected from each of the 3 divisions using simple random sampling (by balloting). They were Kosofe LGA, Amuwo-Odofin LGA, and Apapa LGA respectively. In the third stage, 2 brothels were selected each from the three LGAs by simple random sampling (by balloting), totaling 6 brothels. Finally, the respondents were selected using the snowball sampling technique. In this technique, 3 FSWs were initially recruited at each of the brothels then each of the initial respondents was asked to recruit additional respondents, this was repeated with all respondents until the desired sample size of 300 respondents were reached. Each participant was categorized based on their charges to clients as high (>N10,000); medium (N5,000- N10,000) or low class $(<\mathrm{N} 5000)$.

The data was collected using an adapted, pretested, semi-structured intervieweradministered questionnaire $(13,14)$. The questionnaire comprised of four sections that comprised the socio-demographic characteristics of respondents, knowledge of HIVI AIDS and HCT, the attitude of respondents towards HCT, utilization, and factors affecting utilization of HCT centers. In the knowledge section, correct responses were scored 1 mark while incorrect responses were scored 0 for all questions. The sum of correct responses that ranged between 0-49 percent was regarded as poor knowledge while 50-100 percent was regarded as good knowledge. Similarly, the respondents' attitude was graded on a fivepoint Likert scale from 1 to 5 from negative to positive responses and scores below $50 \%$ were regarded as negative attitude and those $50 \%$ and above were regarded as positive attitudes. IBM SPSS Statistics version 23 was used to analyze the data. Frequency distribution and percentage were represented in tables and narratives. Approval from the Health Research and Ethics Committee of Lagos University Teaching Hospital (LUTH) was obtained to carry out the research. Informed consent was obtained from the participant before administering the questionnaire. Participation was voluntary and every finding was treated with the utmost confidentiality. 


\section{Results}

In table 1, the majority (63.0\%) of the respondents were between 21-30 years and were single $(68.7 \%)$. The mean age of respondents was $27.1 \pm 5.4$ years while only $3.3 \%$ of them indicated that they were married. A few $(4.0 \%)$ of the respondents had no formal education, $76.0 \%$ had secondary school education, while $10.0 \%$ had tertiary education. Approximately half $(49.7 \%)$ of the respondents had been involved in sex work for more than 2 years and $45.0 \%$ had been engaged in sex work for $1-2$ years. More than half $(57.7 \%)$ of the respondents indicated that they were in the low-class of FSWs.

Table 1: Socio-demographic characteristics of respondents

\begin{tabular}{lcc}
\hline \multicolumn{1}{c}{ Variable } & Frequency $(\mathbf{n}=\mathbf{3 0 0})$ & Percentage $\mathbf{( \% )}$ \\
\hline Age (Years) & 42 & 14.0 \\
$\leq 20$ & 189 & 63.0 \\
$21-30$ & 67 & 22.3 \\
$31-40$ & 2 & 0.7 \\
$41-50$ & 206 & 68.7 \\
Marital Status & 10 & 3.3 \\
Single & 82 & 27.3 \\
Married & 2 & 0.7 \\
Divorced/separated & 12 & \\
Widowed & 30 & 4.0 \\
Educational level & 228 & 10.0 \\
No Formal Education & 30 & 76.0 \\
Primary & & 10.0 \\
Secondary & 15 & \\
Tertiary & 136 & 5.0 \\
Years of experience & 149 & 45.3 \\
Less than 1 year & & 49.7 \\
1-2years & 173 & \\
Greater than 2 years & 102 & 57.7 \\
Category & 25 & 34.0 \\
Low class & & 8.3 \\
Middle class & & \\
High class & &
\end{tabular}

Almost all $(96.0 \%)$ of the respondents had heard of HIV counseling and testing (HCT) centers, and $93.0 \%$ knew that HIV can be transmitted from one person to another. Concerning knowledge, $96.3 \%$ of the FSWs knew the various methods that HIV could be transmitted. About two-thirds (66.0\%) of the respondents indicated that sex work exposed them to high risk of being infected while $93.3 \%$ and $62.5 \%$ revealed that HIV is preventable and can be prevented by the consistent use of condoms respectively. In table 2 , more than three-quarter $(84.3 \%)$ of the respondents indicated that AIDS is incurable and $87.3 \%$ stated that they knew a test center for HIV test. This study showed that $78.7 \%$ of the respondents had been tested for HIV and $67.4 \%$ of the respondents had good knowledge of HCT.

Table 2: Knowledge of HIVIAIDS and HCT

\begin{tabular}{lcc}
\hline \multicolumn{1}{c}{ Variable } & Frequency $(\mathbf{n}=\mathbf{3 0 0})$ & Percentage (\%) \\
\hline Heard of HCT centers & & \\
Yes & 288 & 96.0 \\
No & 12 & 4.0 \\
Sources of information about HCT center $(\mathbf{n = 2 8 8})$ & 113 & 39.2 \\
Friends & 77 & 26.7 \\
Media & 62 & 21.5 \\
Family Members & 35 & 12.2 \\
Health care workers & 1 & 0.3 \\
Others & & 84.7 \\
Can receive HIV information at the HCT center $(\mathbf{n = 2 8 8})$ & 244 & 4.5 \\
Yes & 13 & \\
No & &
\end{tabular}




\begin{tabular}{|c|c|c|}
\hline Don't know & 31 & 10.8 \\
\hline \multicolumn{3}{|c|}{ HIV can be transmitted from one person to another } \\
\hline Yes & 279 & 93.0 \\
\hline No & 18 & 6.0 \\
\hline Don't know & 3 & 1.0 \\
\hline \multicolumn{3}{|l|}{ Modes of HIV transmission* } \\
\hline Sharing of sharp objects & 289 & 96.3 \\
\hline Blood transfusion & 258 & 86.0 \\
\hline Mosquito bites & 35 & 11.7 \\
\hline Unprotected sex with an infected person & 289 & 96.3 \\
\hline From infected mother to her unborn child & 214 & 71.3 \\
\hline \multicolumn{3}{|c|}{ Sex Work exposes one to a higher risk of being infected } \\
\hline Yes & 198 & 66.0 \\
\hline No & 22 & 7.3 \\
\hline \multirow{2}{*}{\multicolumn{3}{|c|}{ HIV is preventable }} \\
\hline & & \\
\hline Yes & 280 & 93.3 \\
\hline No & 18 & 6.0 \\
\hline Don't know & 2 & 0.7 \\
\hline \multicolumn{3}{|l|}{ HIV can be prevented by what means $(n=280)$} \\
\hline Abstinence & 56 & 20.0 \\
\hline Consistent use of condoms & 175 & 62.5 \\
\hline Not sharing object & 49 & 17.5 \\
\hline \multicolumn{3}{|l|}{ AIDS is incurable } \\
\hline Yes & 253 & 84.3 \\
\hline No & 9 & 3.0 \\
\hline Don't know & 38 & 12.7 \\
\hline \multicolumn{3}{|l|}{ Who should be tested } \\
\hline Everyone & 194 & 64.7 \\
\hline People who have unprotected sex & 50 & 16.7 \\
\hline People who have sex with HIV infected persons & 40 & 13.3 \\
\hline People who use needles for tattoos, piercings & 1 & 0.3 \\
\hline Only sexually active people & 15 & 5.0 \\
\hline \multicolumn{3}{|l|}{ Know where to go to get an HIV test } \\
\hline Yes & 262 & 87.3 \\
\hline No & 5 & 1.7 \\
\hline Not sure & 33 & 11.0 \\
\hline \multicolumn{3}{|l|}{ Ever been tested to see if you have the HIV } \\
\hline Yes & 236 & 78.7 \\
\hline No & 64 & 21.3 \\
\hline \multicolumn{3}{|l|}{ Did you find the test helpful $(n=236)$} \\
\hline Yes & 185 & 78.4 \\
\hline No & 32 & 13.6 \\
\hline \multicolumn{3}{|l|}{ Overall knowledge } \\
\hline Good & 194 & 67.4 \\
\hline Poor & 94 & 32.6 \\
\hline
\end{tabular}

${ }^{*}$ Multiple responses allowed

In table 3 , the majority $(70.1 \%)$ of the respondents agreed that it was good to know one's HIV status while $32.6 \%$ were of the view that HIV test should be done every six months. Approximately $62 \%$ of the respondents were willing to be counseled and tested for HIV at an
HCT center and $55.9 \%$ agreed that condoms were useful in protecting them against HIV. Over half $(54.2 \%)$ of the respondents agreed that condoms should be used regularly and $48.3 \%$ were willing to introduce a colleague to an HCT center.

Table 3: Attitude towards HIV counseling and testing (HCT)

$\begin{array}{lccccc}\text { Variables } & \begin{array}{c}\text { Strongly } \\ \text { Agree } \\ \text { frequency }\end{array} & \text { Agree } & \text { Disagree } & \begin{array}{c}\text { Strongly } \\ \text { Disagree }\end{array} & \text { Indifferent } \\ & (\%) & (\%) & (\%) & (\%) & (\%) \\ & \text { frequency } & \text { frequency } & \text { frequency } & \text { frequency } \\ \end{array}$




\begin{tabular}{|c|c|c|c|c|c|}
\hline Think it is necessary to know one's HIV status & $84(29.2)$ & $202(70.1)$ & $1(0.3)$ & $1(0.3)$ & $1(0.3)$ \\
\hline $\begin{array}{l}\text { HCT is useful for everyone to ensure they know } \\
\text { their HIV status }\end{array}$ & $172(59.7)$ & 115 (39.9) & $0(0.0)$ & $1(0.3)$ & $1(0.3)$ \\
\hline $\begin{array}{l}\text { HIV test should be done for sexually active } \\
\text { people only }\end{array}$ & $3(1.0)$ & $87(30.2)$ & $113(39.2)$ & $45(15.6)$ & 40 (13.9) \\
\hline $\begin{array}{l}\text { HIV testing is only necessary for sick people } \\
\text { and should not be done in healthy people }\end{array}$ & $2(0.7)$ & $88(30.6)$ & $138(47.9)$ & $36(12.5)$ & $24(8.3)$ \\
\hline $\begin{array}{l}\text { Counselling and testing for HIV should take } \\
\text { place at a HCT center }\end{array}$ & 179 (62.2) & 92 (31.9) & $8(2.8)$ & $4(1.4)$ & $5(1.7)$ \\
\hline $\begin{array}{l}\text { Feel HCT centers should be made more readily } \\
\text { accessible to people }\end{array}$ & $168(58.3)$ & $111(38.5)$ & $5(1.7)$ & $2(0.7)$ & $2(0.7)$ \\
\hline Positive HIV test is a death sentence & $3(1.0)$ & $166(57.6)$ & $87(30.2)$ & $12(4.2)$ & $20(6.9)$ \\
\hline $\begin{array}{l}\text { Whoever tests positive got it from the test kit } \\
\text { and not from a previous infection }\end{array}$ & $2(0.7)$ & 161 (55.9) & 85 (29.5) & $16(5.6)$ & $24(8.3)$ \\
\hline $\begin{array}{l}\text { HCT services in Lagos State are substandard } \\
\text { because it is free of charge }\end{array}$ & $3(1.0)$ & $68(23.6)$ & 32 (11.1) & $133(46.2)$ & 52 (18.1) \\
\hline Condoms are protective against HIV & $110(38.2)$ & $163(56.6)$ & $3(1.0)$ & $1(0.3)$ & $11(3.8)$ \\
\hline $\begin{array}{l}\text { Willing to introduce colleagues to an HCT } \\
\text { center }\end{array}$ & $139(48.3)$ & $83(28.8)$ & $3(1.0)$ & $42(14.6)$ & $21(7.3)$ \\
\hline Overall attitude & \multicolumn{2}{|c|}{ Frequency } & \multicolumn{3}{|c|}{$\%$} \\
\hline Negative & \multirow{2}{*}{\multicolumn{2}{|c|}{$\begin{array}{c}72 \\
216\end{array}$}} & \multicolumn{3}{|c|}{25.0} \\
\hline Positive & & & \multicolumn{3}{|c|}{75.0} \\
\hline
\end{tabular}

The overall attitude scores depicted that $75.0 \%$ had a positive attitude towards HCT. The utilization of HCT is represented in table 4. About $60.4 \%$ of the respondents indicated that they had access to HCT centers. The main place of access to HCT service as specified by respondents was Primary Health Centers $(34.5 \%)$. More than half $(55.6 \%)$ revealed that they had sought service at an HCT site before.

Table 4: Utilization of HIV counseling and testing centers

\begin{tabular}{lcc}
\hline \multicolumn{1}{c}{ Variable } & Frequency & Percentage (\%) \\
\hline Have access to HCT Centre (n=288) & 174 & 60.4 \\
Yes & 114 & 39.6 \\
No & & \\
Nearest HCT Centre is over 25km (n=174) & 85 & 48.9 \\
Yes & 89 & 51.1 \\
No & & \\
Place of access to HCT service (n=174) * & 28 & 16.1 \\
Private hospital & 60 & 34.5 \\
Primary Health Centre (PHC) & 41 & 23.6 \\
General Hospital & 18 & 10.3 \\
Tertiary Hospital & 43 & 24.7 \\
Mobile HCT centers & 25 & 14.4 \\
Organized outreaches & 15 & 8.6 \\
Faith-based centers & 11 & 6.3 \\
Pharmacy/ Chemist & 24 & 13.8 \\
Private Doctor/ Clinic & 5 & 2.9 \\
Business premise/workplace & & \\
Ever sought service at any HCT site before (n=288) & 160 & 55.6 \\
Yes & 128 & 44.4 \\
No & & \\
Engaged in sex with a person whose HIV status is & & \\
unknown in the past 12 months (n=300) & 148 & 49.3 \\
Yes & 152 & 50.7 \\
No & & \\
Engaged in sex with a person whose HIV status \\
was different from yours in the past 12 months (300) \\
Yes
\end{tabular}

OVERALL UTILIZATION SCORE 


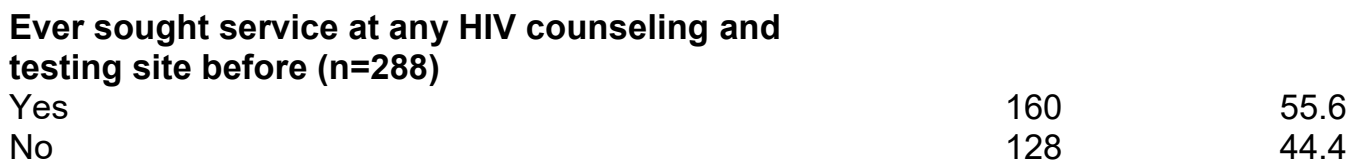

\section{*Multiple responses allowed}

In table 5, the majority of the respondents revealed that the main reasons for not taking HIV tests were fear of a positive result $(90.6 \%)$ and fear of rejection by family and society $(6.3 \%)$. The main reasons for not visiting any HCT center before were distance to the HCT center $(67.2 \%)$ and worry about discrimination of FSW status $(25.0 \%)$. The main reasons for visitation to the testing center by respondents were to know their HIV status $(79.4 \%)$ and for blood transfusion purposes (28.8\%). Also, $66.9 \%$ stated that their last experience at the HCT center was good.

Table 5: Factors affecting the utilization of HCT

\begin{tabular}{|c|c|c|}
\hline Variable & Frequency & Percentage (\%) \\
\hline \multicolumn{3}{|c|}{ Main reasons for not taking the HIV test $(n=64)$} \\
\hline Expensive & 1 & 1.6 \\
\hline Fear of a positive result & 58 & 90.6 \\
\hline Fear of rejection by family and society & 4 & 6.3 \\
\hline Takes time for the result to be out & 1 & 1.6 \\
\hline \multicolumn{3}{|c|}{ Reason for not visiting any HCT center before $(n=128)^{*}$} \\
\hline Distance to the HCT center & 86 & 67.2 \\
\hline Worry about discrimination of FSW status & 32 & 25.0 \\
\hline Stigmatization & 19 & 14.8 \\
\hline Lack of Confidentiality & 17 & 13.3 \\
\hline Fear of being seen by people & 17 & 13.3 \\
\hline No support by the manager & 14 & 10.9 \\
\hline Negative attitudes of the Health Worker & 14 & 10.9 \\
\hline Unreliable test result & 13 & 10.2 \\
\hline Not willing to attend HCT center for testing & 12 & 9.4 \\
\hline Payment for services & 8 & 6.3 \\
\hline Religious belief & 7 & 5.5 \\
\hline Delay in results & 5 & 3.9 \\
\hline \multicolumn{3}{|c|}{ Reason for visiting the testing center $(n=160)$} \\
\hline To know my HIV status & 127 & 79.4 \\
\hline It was enforced & 24 & 15.0 \\
\hline Blood transfusion purposes & 46 & 28.8 \\
\hline School admission purposes & 16 & 10.0 \\
\hline Others & 1 & 0.6 \\
\hline \multicolumn{3}{|c|}{$\begin{array}{l}\text { Description of last experience at the site you } \\
\text { visited for the HIV Counselling and Testing }(n=160)\end{array}$} \\
\hline Good & 107 & 66.9 \\
\hline Fair & 49 & 30.6 \\
\hline Bad & 4 & 2.5 \\
\hline
\end{tabular}

\section{Discussion}

This study assessed the knowledge, attitude, and utilization of HCT by 300 BBFSWs in Lagos State. Almost all the respondents were aware of HCT centers, through friends, the media, family members, and healthcare workers in this study. This was similar in other studies however, media was the main source of information among students in a tertiary institution in Abia State, southeast Nigeria (15) while it was the health workers in a study among youths in Gulu, Northern Uganda (11). Almost all of the respondents knew that HIV is transmissible from one person to another majorly by unprotected sex with an infected person, sharing of sharp objects and transmission from an infected mother to her unborn child and this is consistent with a study among FSWs in Kano (16). In Papua New Guinea, the majority were aware that HIV is transmissible through sexual contact followed by pregnant mothers to unborn children (17). Transmission from infected blood and unprotected sexual intercourse were the two most common means listed by FSWs in Shanghai, China (18). In all these studies, the 
FSWs were aware that sexual intercourse was an important means of transmission of HIV. About two-thirds of the participants in this study believed that their job put them at a high risk of being infected and only a few of the respondents did not agree that their job exposes them to HIV. Similarly, one out of five sex workers perceived that they had a high or moderate risk of contracting HIV in a Korean study (19). This finding differs from a study among FSWs in four cities in Nigeria where the respondents underestimated the risk of infections from their job as sex workers but rather a strong belief in fatalism and predestination (20). Also, $80 \%$ of FSWs who participated in a study in Aden, Yemen (21), reported low perceived risk. Rationalization and defense of risky behaviors is a typical psychological response to threat and anxiety of belief and behavior discrepancies as explained by the principle of balance theory $(20,22)$. Most $(93.3 \%)$ respondents in this study thought that HIV was preventable, and the majority indicated the use of condoms as a method of prevention. In the Yemen study, the respondents were less likely to use condoms and to seek medical assistance for sexually transmitted infections (STI) which increases the vulnerability to HIV (21). Existing research suggests that risk perception is a critical determinant of health behavior (23).

Over three-quarters of the respondents in this study confirmed they have been tested for HIV in the past which is similar to a study conducted among Cameroonian and Ethiopian female sex workers $(24,25)$. About a third of the respondents were of the view that HIV tests should be done every six months which is also consistent with the Ethiopian study (25). The majority of the respondents were willing to be counseled and tested for HIV at an HCT center similar to the study conducted in the tertiary institution in Abia State, Nigeria (15). However, more than half of the respondents in this study felt HCT centers should be made more readily accessible. About half (54.2\%) of the respondents strongly agreed that on the need for regular use of condoms and this was lower than the study in Ethiopia, where $79.3 \%$ of the respondents advocate correct and consistent use of condoms (25). This study revealed an overall positive attitude of $75 \%$ which is higher than the findings from a study conducted in Kenya (26).

Over half of the respondents in this study utilized the HCT centers lower than two-thirds of them who had access to the centers. This finding for utilization was similar among the FSWs in Kenya (26). PHC was the commonest place of access to HCT in this study similar to the study done in Abia State, Nigeria (15). The main reason for not taking the HIV test as indicated by respondents was majorly the fear of a positive result. For the respondents in this study who had not visited any HCT center before, the main complaint was the distance to the HCT $(67.2 \%)$ followed by stigmatization $(14.8 \%)$ and lack of confidentiality (13.3\%) which differed from a study in Abia State (15) in which lack of awareness of HIV testing centers $(37.1 \%)$, followed by fear of positive test result $(22.9 \%)$ and the lack of desire to get tested for HIV in $22.4 \%$ were their main reasons for not visiting the HCT center. However, a study in South Africa study, showed that slightly more than half $(52.0 \%)$ of the survey participants cited stigma or negative attitudes as a factor that deterred HIV testing (27).

The main reason for visiting the HCT centers by the majority of respondents in this study was the need to know their HIV status similar to what was reported in a study in Cameroon (25). Other reasons for HIV testing in this study were for school admission (10.0\%), blood transfusion $(28.8 \%)$ and when enforced $(15.0 \%)$ while in the Cameroonian study, it was for school admission $(22.0 \%)$, illnesses $(10.2 \%)$ and marriage purposes (8.5\%) (25). The majority of the FSWs in this study described their last experience at the HCT center as "good", similar to the study in Abia State, Nigeria (15). Among the respondents who had not visited HCT centers before, reasons given included stigmatization (14.8\%), discrimination (13.3\%), negative attitude of health workers administering HCT $(10.9 \%)$, the distance of HCT center $(67.2 \%)$, and doubt about client confidentiality $(13.3 \%)$. Similar findings were observed in a recent study in Abuja, Nigeria, where stigmatization and discrimination, health workers' attitude while offering HCT service, location of HCT center, and client confidentiality were factors militating against HCT utilization (1).

The study contributes to our understanding of BBFSWs and their HCT knowledge and utilization in Lagos State. A potential source of bias for the study is with the sampling method as research participants are likely to refer people they know and have similar traits. Secondly, an additional qualitative input such as a focus group discussion as part of this study would have allowed more detailed information on beliefs, opinions, and experiences of the respondents on HCT utilization.

\section{Conclusion}

In conclusion, there was a good knowledge of HIV and a positive attitude towards HCT services by the respondents. The main reasons 
for the non-utilization of HCT centers included distance to the centers and worry about sex work discrimination. It is recommended that more HCT centers should be made available for use and HIV-stigma related issues should be adequately addressed.

\begin{tabular}{|c|c|}
\hline BBFSWs: & $\begin{array}{l}\text { Brothel-Based Female Sex } \\
\text { Workers }\end{array}$ \\
\hline FSWs: & Female Sex Workers \\
\hline HIVIAIDS: & $\begin{array}{l}\text { Human Immunodeficiency } \\
\text { Virus/Acquired } \\
\text { immunodeficiency Syndrome }\end{array}$ \\
\hline HCT: & $\begin{array}{l}\text { HIV counseling and testing } \\
\text { services }\end{array}$ \\
\hline LGA: & Local Government Area \\
\hline LSACA: & $\begin{array}{l}\text { Lagos State AIDS Control } \\
\text { Agency }\end{array}$ \\
\hline LUTH: & $\begin{array}{l}\text { Lagos University Teaching } \\
\text { Hospital }\end{array}$ \\
\hline $\begin{array}{l}\text { PHC: } \\
\text { STI: }\end{array}$ & $\begin{array}{l}\text { Primary Health Centre } \\
\text { Sexually Transmitted } \\
\text { Infections }\end{array}$ \\
\hline UNAIDS: & $\begin{array}{l}\text { The Joint United Nations } \\
\text { Programme on HIVIAIDS }\end{array}$ \\
\hline VCT: & $\begin{array}{l}\text { Voluntary Counselling and } \\
\text { Test centers }\end{array}$ \\
\hline
\end{tabular}

\section{Declarations}

Ethics approval and consent to participate The study was approved by Lagos University Teaching Hospital Health Research and Ethics Committee with approval number ADM/DCST/HREC/APP/1832.

\section{Consent for publication}

The authors hereby give consent for the publication of our work under the creative commons CC Attribution-Noncommercial 4.0 license.

\section{Availability of data and materials}

The data and materials associated with this research will be made available by the corresponding author upon reasonable request.

\section{Competing interests}

The authors have declared no conflict of interest.

\section{Funding}

The authors received no research funding.

\section{Authors' contributions}

$\mathrm{OA}$ and $\mathrm{OO}$ conceived of the presented idea and the study design. OA, OO, OE, and EA processed the data, interpreted the analysis, and drafted the manuscript. All authors discussed the results, commented on the manuscript, and approved the final manuscript.

\section{Acknowledgment}

None.

\section{References}

1. Bibiana NE, Emmanuel PO, Amos D, Ramsey YM, Idris AN. Knowledge, attitude, and factors affecting voluntary HIV counseling and testing services among women of the reproductive age group in an Abuja Suburb community, Nigeria. Medical Journal of Zambia. 2018;45(1):13-22.

2. Patterson $T L$, Volkmann $T$, Gallardo $M$, Goldenberg S, Lozada R, Semple SJ, Anderson CM, Strathdee SA. Identifying the HIV transmission bridge: which men are having unsafe sex with female sex workers and with their wives or steady partners? Journal of acquired immune deficiency syndromes (1999). 2012 Aug 1;60(4):414. https://doi.org/10.1097/qai.0b013e3182569 3f2

3. Shete A. Current trends in HIVIAIDS. J HIV. 2013; 1:102.

4. Holland K, Nicholls E. How Close Are We to an HIV Cure? Healthline [Internet]. [cited 2020 Jun 3]. Available from: https://www.healthline.com/health/hivaids/cure

5. Avert. HIV prevention programmes overview. Avert [Internet]. [cited 2020 Jun 3]. Available from https://www.avert.org/professionals/hivprogramming/prevention/overview

6. Nigeria Global Al. Response Progress Report GARPR: 2012. Nigeria National Agency for the Control of AIDS. Abuja, Nigeria. 2012. Available from: https://naca.gov.ng/nigeria-global-aidsresponse-progress-report-garpr-2012/

7. UNAIDS. UNAIDS World AIDS day report. Available from https://www.unaids.org/en/resources/press centre/pressreleaseandstatementarchive/2 011/november/20111121wad2011report

8. FMoH. National HIVIAIDS and Reproductive Health and Serological Survey, 2012 (NARHS Plus). https://doi.org/10.4103/2321-9157.135744

9. Joint United Nations Programme on HIVIAIDS. UNAIDS 2011-2015 Strategy: Getting to Zero. https://doi.org/10.1007/9783-319-46013-0 3

10. World Health Organization. Global health sector strategy on HIVIAIDS 2011-2015. Available 
https://www.who.int/hiv/pub/hiv strategy/en I

11. Kitara DL, Amone C, Okello C. Knowledge and misconceptions about HIV counseling and testing (HCT) among the post-conflict youths of Gulu, Northern Uganda. A prospective study design. Pan African Medical Journal. 2012;12(1). https://doi.org/10.4314/ajid.v6i1.77737

12. Cochran W. Sampling Techniques, 2nd Edition. 2nd edition. New York: John Wiley and Sons; $1963 . \quad 413 \quad$ p. https://doi.org/10.1017/s001309150002572 4

13. Eluwa GI, Strathdee SA, Adebajo SB, Ahonsi B, Azeez A, Anyanti J. Sexual risk behaviors and HIV among female sex workers in Nigeria. JAIDS Journal of Acquired Immune Deficiency Syndromes. 2012 Dec 1;61(4):507-14. https://doi.org/10.1097/qai.0b013e31826df b41

14. Oladunni TM, Osezua C. Acceptance and uptake of HIV counseling and testing by youth corp members in Osun State, Nigeria. International Journal of Asian Social Science. 2013;3(6):1381-8.

15. Onyeonoro UU, Emelumadu OF, Chuku A, Kanu OO, Ebenebe UE, Onwukwe N, Ndukwe E. Knowledge and utilization of HIV counseling and testing services among students of a tertiary institution in Abia State, southeast Nigeria. J HIV Hum Reprod. 2014 Jan $1 ; 2(1): 8-14$. https://doi.org/10.4103/2321-9157.135743

16. Lawan UM,1* Abubakar S1 and Aisha Ahmed2. Risk Perceptions, Prevention, and Treatment Seeking for Sexually Transmitted Infections and HIVIAIDS among Female Sex Workers in Kano, Nigeria. Afr J Reprod Health 2012; 16[1]:61-67.

17. Bruce E, Bauai L, Sapuri M, Kaldor JM, Fairley CK, Keogh LA. HIV knowledge, risk perception, and safer sex practices among female sex workers in Port Moresby, Papua New Guinea. International journal of women's health. 2011; 3:53. https://doi.org/10.2147/ijwh.s14669

18. Cai Y, Shi R, Shen T, Pei B, Jiang X, Ye X, Xu G, Li S, Huang H, Shang M. A study of HIVIAIDS-related knowledge, attitude and behaviors among female sex workers in Shanghai China. BMC Public Health. 2010 Dec $1 ; 10(1): 377$. https://doi.org/10.1186/1471-2458-10-377

19. Hlaing TT. Analyzing knowledge, attitude, and practices on HIVIAIDS among female sex workers (Doctoral dissertation, KDI School). Available from https://archives.kdischool.ac.kr/handle/111 25/30324

20.Ankomah A, Omoregie G, Akinyemi Z, Anyanti J, Ladipo O, Adebayo S. HIVrelated risk perception among female sex workers in Nigeria. HIVIAIDS (Auckland, NZ). 2011; 3:93. https://doi.org/10.2147/hiv.s23081

21. Atulhofer A, BoAicevic I. HIV bio-behavioral survey among FSWs in Aden, Yemen. National AIDS and STI Control Programme, Ministry of Public Health \& Population, Sana'a, Yemen. 2008.

22. Heider F. The psychology of interpersonal relations. New York, NY: Wiley; 1958

23. Ferrer RA, Klein WM. Risk perceptions and health behavior. Current opinion in psychology. 2015 Oct 1; 5:85-9.

24. Lai Y. Regional Differences in HIV Epidemic and HIV testing services usage among Cameroonian female sex workers: Comparing Grand North and Grassland Regions (Doctoral dissertation, Johns Hopkins University). Available from https://jscholarship.library.jhu.edu/bitstr eam/handle/1774.2/38095/LAlTHESIS-

2015.pdf? sequence=1\&isAllowed=y

25. Ebrahim J. Assessment of Risk Factors for HIVIAIDS among Female Sex Workers (FSWs) in Dessie Town (Doctoral dissertation, St. Mary's University). Available from https://pdfs.semanticscholar.org/4a3b/821a 0313b06283f83578e780432c7f04693e.pdf

26. Nyamu JN. Human immunodeficiency virus knowledge, attitude, and practice among female sex workers in korogocho slum, Nairobi, Kenya (Doctoral dissertation). Available from: http://erepository.uonbi.ac.ke/bitstream/han dle/11295/102659/FINAL MARY\%20NJIIR \%20PROJECT\%20(1).pdf?sequence=1

27. Chimoyi L, Tshuma N, Muloongo K, Setswe G, Sarfo B, Nyasulu PS. HIV-related knowledge, perceptions, attitudes, and utilization of HIV counseling and testing: a venue-based intercept commuter population survey in the inner city of Johannesburg, South Africa. Global health action. 2015 Dec 1;8(1):26950.

https://doi.org/10.3402/gha.v8.26950 